\title{
Optimizatimizing The Senior Public Health Cadres in Tapakis Village, Ulakan Tapakis District, Padang Pariaman Regency
}

\author{
Hilda Hidayat ${ }^{1}$, Sevilla Ukhtil Huvaid ${ }^{2}$ \\ \{hildahidayat15@gmail.com¹,sevilla_0428@yahoo.com²\} \\ Faculty of Public Health, Baiturrahmah University, Padang, Indonesia ${ }^{1,2}$
}

\begin{abstract}
The low knowledge of Senior Public Health cadres has a negative impact on performance. The former public health cadres were not active even though the Public Health Center was there. No training was scheduled to maintain and upgrade the skills and knowledge of how to take care of the senior. The current research focuses on optimizing the senior former public health cadres in Tapakis Village, Padang Pariaman Regency. The program includes lectures, discussions, and workshops. The training material covers understanding, importance, objectives, implementing activities, main tasks \& functions, efforts to deal with difficulties, knowledge, and the essential skills to take care of the senior. We also conducted discussions with the participants about their duties and responsibility as Senior Care cadres. The participant was very enthusiastic about asking questions. They were committed to carrying out their responsibility to take care of seniors in Tapakis Village. The participants include 22 Senior Public Health cadres. This activity took place on February 17, 2019. The results obtained by the participants responded positively and were very enthusiastic about participating in the training. The pre-test and post-test values indicate changes in the increase in knowledge that is the difference in the average knowledge before counseling (6.18), after counseling (11.23) and the value of $p=0.000$
\end{abstract}

Keywords: Senior, basic responsibility, Public Health cadre, training

\section{Introduction}

National development in various fields has improved the quality of health and socioeconomic conditions of society in general. Indonesia's life expectancy has significantly increased. The results of the 2010 Population Census (SP) indicate that the life expectancy is 70.7 years. It is far higher than the previous three or four decades of life expectancy, which is under 60 years. The increase in life expectancy has increased the number of the older population (senior) and changed the structure of Indonesia's population [1].

Seniors are people age 60 years and above. Based on Law No. 13 of 1998 on Senior Citizens Welfare. Globally, the number of seniors continues to increase. The senior population in Indonesia is predicted to increase higher than the world senior populations after 2100 . The elderly population in Indonesia in 2013 was $8.9 \%$ of the total population, and according to estimates by the Central Statistics Agency (BPS), Indonesia will become senior period (aging) country with $10 \%$ of the population are 60 years and above in 2020 [2]. 
Law Number 36 of 2009 article 138, Section 1 states that health cares are responsible for maintaining a healthy and productive senior. Paragraph 2 indicates that the government must provide health care facilities, and help the seniors to be independent, continue to live independently, both socially and economically

[3].

The government had issued various policies and programs, including Government Regulation Number 43 of 2004 on Implementation of Efforts to Increase the Welfare for the Senior. The regulation includes: 1) Religious and mental-spiritual services such as the construction of religious facilities with accessibility services for the seniors; 2) Health services through increased healing efforts (curative), expanded in the geriatric/gerontological service area; 3) Services for public infrastructure, including ease of use of public facilities, cost relief, travel mobility, provision of special recreational and sports facilities; 4) Ease of use of public facilities, such as government administration services (lifelong identity cards), health services at government-owned health facilities, services, and cost relief for the purchase of travel tickets, accommodation, tax payment, purchase of recreational tickets, provision of special seat, providing special counters, providing special tourist cards, prioritizing the seniors.

The government policies have strongly supported the senior community to be healthy and productive in carrying out life. However, there are still many problems found in taking care of seniors, especially in health issues. The physical and psychological aspects of seniors in the senior center are relatively low, while their social aspects are relatively high [4].

All of the above are the effects of poor quality of life for seniors. It can be caused by an increasingly weak physical condition, poor personal relationships, lack of opportunities to obtain information, new skills, and so on. By increasing age, physiological function decreases due to degenerative processes. Besides, the degenerative process may affect immunity, which makes the senior susceptible and vulnerable. Non-communicable diseases in seniors include hypertension, stroke, diabetes mellitus, and arthritis or rheumatism. Infectious diseases suffered are tuberculosis, diarrhea, pneumonia, and hepatitis.

Based on Susenas data in 2012, more than half of the elderly $(52.12 \%)$ experienced health complaints in the past month, and there were no differences in the elderly who experienced health complaints based on sex (50.22\% for men; $53.74 \%$ for women) [5].

The research result of Pera Siahaan, et al. about intervention by giving back massage for 2 (two) days for 30 minutes/day can reduce the scale of moderate rheumatic pain. In addition to massage done to reduce rheumatic disease in the elderly, also with therapy and joint senior exercise. Elderly exercise is carried out once a week. It aimed to improve the health of seniors and reduce rheumatic diseases [6].

Based on the results of the latest study from Qing (2008), the prevalence of rheumatic pain in several ASEAN countries was 26.3\% Bangladesh, 18.2\% India, 23.6-31.3\% Indonesia, $16.3 \%$ Philippines, and 14.9\% Vietnam. It means that Indonesia has a sufficient prevalence of rheumatic pain. These conditions can reduce the productivity of the country due to the limitations of the physical function that affect the quality of life [7].

The results of an initial survey conducted by students of the Faculty of Public Health in Nagari Tapakis, Padang Pariaman District, found that the village had a relatively large number of seniors groups. The number of seniors was quite large, and many of them faced degenerative diseases. The preliminary survey data shows that most of the seniors have health problems such as rheumatism (81\%), hypertension (28\%), smoking (34\%), and do not consume osteoporosis-preventing milk $(87 \%)$. The number of health problems $\&$ the high 
incidence of degenerative diseases certainly influences the level of productivity and will have an impact on their quality of life. Such conditions require promotive and preventive efforts that must be carried out by the government to improve the quality of their life. Nagari Tapakis, which consists of 14 villages, has only one Senior Care Center. Moreover, many cadres of Public Health Care are active, as found during the results of interviews with cadres. They mentioned that the only new program after the initiating of the Senior Health Care is gymnastics. Therefore it is necessary to update the Senior Care cadres skills in Nagari Tapakis to carry on the Senior Health Care Center.

\section{Method}

This program had been done for 22 Senior Health Care cadres in Kenagarian Tapakis, Padang Pariaman Regency. It was conducted on February 17, 2019. The priority Issues: the low level of knowledge and skills of the Senior Health Care Centercadres in Kenagarian Tapakis, Padang Pariaman Regency, which affected their performance. The initial survey indicates that the cadres for Senior Health Care center are the same person for those who run the Child Health Care center. Of course, it becomes extra works for the cadres. Moreover, there is also no skill upgrading since the Senior Health Care center was initiated.

The method of activities used in resolving the problems prioritized above are as follows:

1. Lecture on the task and responsibility of Senior Health Care cadres

2. Senior Counseling \& Gymnastics Practices

3. Discussion (question and answer) material that has been given during the lecture

4. Do pre-test and post-test.

The work procedures in this training activity include:

1. The trainees work on a pre-test

2. Training participants get material exposure to the tasks and functions of Senior Health Care cadres

3. Training participants practice counseling and elderly exercise

4. Training participants and speakers conduct discussions (questions and answers) about the material that has been presented

5. The trainees work on the post-test

6. The training participants put forward the obstacles/obstacles as a Senior Health Care cadre

7. The participants were competing to answer questions about the material provided by the community service team to get a door prize.

Partner participation will determine the success of the community service activities that will be carried out. Among the most important partner is the local government responsible for providing the places and facilities needed for training activities. By the upgrade knowledge and skills, it is expected that cadre

can provide the best service for the Senior Health Care center in Kenagarian Tapakis, Ulakan Tapakis District, Padang Pariaman Regency. 


\section{Result}

Results of Activity Implementation

1. Training materials

a. The material presented at the Senior Health Care training includes:

b. Definition of Senior Health Care center The importance of Senior Health Care center

c. Target and aims of the Senior Health Care activities

d. Basic Tasks \& Functions of the Senior Health Care Cadres

e. Deal with problem during regarding the Senior Health Care center

f. Basic Knowledge and skills of Senior Health Care cadres

g. Tips for dealing with seniors.

2. Implementation

The stages of the implementation of the Senior Health Care training activities carried out in Kenagarian Campago can be seen in Table 1 below:

Table 1. Stages of Implementation of Senior Health Care Training Activities in Kenakari Tapakis, Padang Pariaman Regency in 2019

\begin{tabular}{ccc}
\hline Theory & Origin Coach & Time \\
\hline Pre-test & Students of PBL FKM Unbrah & 30 minutes \\
& Hilda Hidayat, SKM, M.Kes & 90 minutes \\
& $\begin{array}{c}\text { Sevilla Ukhtil Huvaid, SKM, M.Kes } \\
\text { Drs Eka Trio Effandilus, M.Si } \\
\text { dr. Rika Amran, MARS }\end{array}$ & \\
& Elder cadres, students, lecturers & 60 minutes \\
\hline Senior Counseling \& & Hilda Hidayat, SKM, M.Kes & 30 minutes \\
Gymnastics Practices & Sevilla Ukhtil Huvaid, SKM, M.Kes & \\
\hline $\begin{array}{c}\text { Discussion and question and } \\
\text { answer }\end{array}$ & Drs Eka Trio Effandilus, M.Si & \\
& dr. Rika Amran, MARS & 10 minutes \\
\hline Giving Door Price & Students of PBL FKM Unbrah & 30 minutes \\
\hline Giving a post-test & PBL students & \\
\hline
\end{tabular}

The activity began with sending invitations to training programs to 28 elderly Posyandu health cadres who came from 14 villages in Tapakis Kanagarian, Padang Pariaman District, each village was represented by two cadres. 22 cadres attended and attended the training from the beginning to the end of the program.

The training showed positive results because the participants responded positively and were very enthusiastic about participating in the training activities. Moreover, the test results of the trainees, both pre-test and post-test can be seen in the following table: 
Table 2. Results of Knowledge Evaluation of Posyandu Cadre Training Participants

\begin{tabular}{ccc}
\hline Variab & Le MeanP-value \\
\hline $\begin{array}{c}\text { Knowledge Before } \\
\text { Counseling }\end{array}$ & 6,18 & 0,000 \\
\hline Knowledge After Counseling & 11,23 & 0,000 \\
\hline
\end{tabular}

The pre-test and post-test values indicate that there was a change in the form of an increase in respondents' knowledge. It can be seen from the average knowledge of respondents before counseling (6.18) and after counseling (11.23) with a value of $p=0,000$.

3. Implementation cost

The following details the costs in the elderly Senior Health Care training activities in Kenagarian Tapakis, Padang Pariaman Regency in 2019:

Table 3. Costs for the Implementation of Senior Health Care Training

\begin{tabular}{|c|c|c|c|}
\hline Material & $\begin{array}{c}\text { Usage } \\
\text { Justification }\end{array}$ & $\begin{array}{l}\text { Unit Price } \\
\text { (Rp) }\end{array}$ & $\begin{array}{l}\text { Amount of Cost } \\
\text { (Rp) }\end{array}$ \\
\hline $\begin{array}{l}\text { Lecturer transportation to the } \\
\text { location of the Community Service }\end{array}$ & 1 time $\mathrm{PP}$ & $500.000,00$ & $500.000,00$ \\
\hline Door Prize & $\begin{array}{c}1 \text { package (3 } \\
\text { pieces) }\end{array}$ & $350.000,00$ & $350.000,00$ \\
\hline $\begin{array}{l}\text { Lunch ( } 28 \text { cadres, } 4 \text { resource } \\
\text { persons, } 18 \text { village staff and } \\
\text { representatives of health centers, } 6 \\
\text { students) }\end{array}$ & $\begin{array}{c}56 \text { people } x 1 \\
\text { times }\end{array}$ & $25,000.00$ & $1.400 .000,00$ \\
\hline Snack & $\begin{array}{l}56 \text { people } \times 1 \\
\text { times }\end{array}$ & $10.000,00$ & $560.000,00$ \\
\hline $\begin{array}{l}\text { ATK (photocopy of material, } \\
\text { photocopy of pre-test and post-test } \\
\text { material, pens, participant } \\
\text { certificates) }\end{array}$ & $\begin{array}{c}28 \text { people x } 1 \\
\text { package }\end{array}$ & $15.000,00$ & $375.000,00$ \\
\hline Cleaning fee & 1 package & $100.000,00$ & $100.000,00$ \\
\hline Reporting \& data processing costs & 1 package & $375.000,00$ & $375.000,00$ \\
\hline $\begin{array}{l}\text { Report duplication \& binding (for } 4 \\
\text { speakers, } 1 \text { faculty, } 1 \text { LPPM, } 1 \\
\text { puskesmas and } 1 \text { kenagarian) }\end{array}$ & 8 copies & $30.000,00$ & $240.000,00$ \\
\hline
\end{tabular}

4. Supporting and Inhibiting Factors

Supporting factors

a. The participants' interest and enthusiasm were quite significant.

b. The local government is willing to give permission and provide facilities so that the training can run well. 
Obstacle factor

The locations of the villages are quite far, which makes the participants challenging to come to the training location.

\section{Discussion}

The results above show that the training of Senior Health Care cadres carried out can improve the knowledge and skills of cadres in carrying out their duties. However, there are still 22 cadres who have not attended the training

This program is very important and has succeeded in improving the skills of the Senior Health Care cadre. It can be seen from the increasing visitors for a medical check after the cadres upgrade their skills. Local government can work with the cadres to provide a better Senior Health Care center. Our method is to provide pre-test and post-test to find out the level of knowledge and understanding of the Senior Health Care cadres about the tasks and responsibilities in running the center.

Knowledge about the task is very important for every individual at work. Good knowledge of the duties and responsibilities within an organization tends to improve the quality of its work. The knowledge affects the understanding, ways of thinking, and analyzing something so that it will automatically give different perceptions to the observed object, which will ultimately change one's behavior.

The training aims to increase knowledge as well as the dedication of cadres so that selfconfidence arises to carry out their duties as Senior Health Care cadres. The main objectives of the training are: The first, to develop the expertise to work faster and effectively. The second is to upgrading skills and knowledge. Third, develop attitudes that lead to the progress of cooperation with colleagues and outside work and with leaders.

In this community service activity, the trainees are allowed to practice and hold discussions (question and answer) with the speaker and the service team about matters related to the material that has been presented. In addition, the training participants were also allowed to express their complaints related to obstacles/obstacles they faced in the field. As for the results of the discussion at this training showed a positive response from the participants, participants were very enthusiastic in the question and answer process, even some participants did not get the opportunity to ask because of limited training time. From the number of questions, the participants showed that the knowledge of the participants who asked was still inadequate, but after getting a further explanation, there was an increase in understanding of the basic concepts of the Lasia Posyandu activities. Based on complaints received from the cadres, it can also be seen that there is still a lack of attention and support given by the Public Health Center and local government to the Senior Health Care cadres in carrying out their duties and functions.

During the programs, the team also provided games. Those who answer the questions correctly will get a prize. This activity can also be considered successful because participants are enthusiastic and involve during the training. 


\section{Conclusion}

The community service has successfully upgraded the skills of the Senior Health Care cadres in running the center. However, some problems need more attention, especially the partnership and the role of the Public Health Center and local government in upgrading the skills of the cadres.

\section{Suggestion}

Public Health Center should actively provide regular upgrading and training for the Senior Health Care cadres. They also need to motivate and support the cadres to provide excellent services for seniors. The Public Health Center also can have a partnership with the local government to provide a well-facilitated Senior Health Care center.

\section{References}

[1] Badan Pusat Statistik. 2014. Life Expectancy of Population of Several Countries (years), 19952015. Accessed September 19, 2019 through https://www.bps.go.id/linkTabelStatis/view/id/1517

[2] Ministry of Health, 2016. Indonesia Health Profile 2014. Jakarta: Ministry of Health Republic of Indonesia; 2015.

[3] RI Ministry of Health. 2013. Elderly Skills and Care. Jakarta. MOH RI.

[4] Furqani, Nusaibah Nur. 2018. Kualitas Hidup Lansia (Studi Kasus di Pondok Lansia Al-Ishlah Blimbing Malang. Skripsi. Fakultas Psikologi Universitas Islam Negeri Maulana Ibrahim Malang. http://etheses.uin-malang.ac.id/13495/1/13410130.pdf

[5] Susenas data for 2012.

[6] Pera Siahaan, Nurhayati Siagian, Yunus Elon. The Effectiveness of Back Massage on the Intensity of Moderate Rheumatism Pain in Older Women in Karyawangi Village, West Bandung Regency. Artikel Penelitian. Jurnal Skolastik Keperawatan (Vol. 3, no.1 Januari - juni 2017 Issn: 2443 0935 E-issn: 2443 - 1699)

[7] Qing (2008). prevalence of rheumatic pain in several ASEAN countries

[8] Fatimah. 2013. Caring for Elderly Humans: An Approach to the Gerontik Nursing Process. Nuha Medika. Jakarta.

[9] Beautiful, Entjang. 2000. Public Health Sciences. PT.Citra Aditya. Jakarta

[10] Ministry of Health, R.I. 2012. Guidelines for Posyandu Management. Jakarta. MOH RI. 